\title{
Effects of ice-slurry and carbohydrate on exercise in the heat
}

\author{
Jo Corbett', Jade E Kirke, Thomas Eckett, Martin J Barwood, James R House \\ From 15th International Conference on Environmental Ergonomics (ICEE XV) \\ Portsmouth, UK. 28 June - 3 July 2015
}

\begin{abstract}
Introduction
There is considerable interest in reducing the ergolytic effect of heat. One approach is to reduce body-heat content through ingesting ice-slurry (IS), which provides a substantially greater heat sink benefit than cool liquids because of the enthalpy of fusion absorbed in the phase change from ice to water [1]. Many studies using IS have employed a formulation containing carbohydrate [2], which is itself ergogenic during prolonged exercise in the heat [3]. Although the separate effects of IS and carbohydrate on performance in the heat are established, it is unclear if there is an interaction when co-ingested. For example, exogenous carbohydrate oxidation is impaired with hyperthermia [4], whereas IS reduces heat stress. This study examined the separate and combined effects of IS and carbohydrate on performance, thermoregulation, substrate utilisation and thermal perception during prolonged cycling exercise in the heat.
\end{abstract}

\section{Methods}

Using a balanced, repeated-measures design, eight physically active males (mean(SD) age 22(2) years; height 1.77 (0.03) $\mathrm{m}$; mass $70.29(9.23) \mathrm{kg}$; cycling peak power output (PPO) 312(51) W; $\mathrm{VO}_{2 \max } 3.31(0.59) \mathrm{L} \mathrm{min}^{-1}$ ) con-

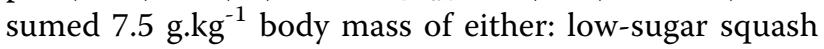
liquid (LI $\left[\sim 7{ }^{\circ} \mathrm{C}\right]$ ); low-sugar squash IS (IS $\left[\sim 0{ }^{\circ} \mathrm{C}\right]$ ); $6 \%$ carbohydrate squash (LIC $\left[\sim 7^{\circ} \mathrm{C}\right]$ ); $6 \%$ carbohydrate IS (ISC $\left[\sim 0{ }^{\circ} \mathrm{C}\right]$ ). Thereafter, participants cycled for 75 minutes at $40 \% \mathrm{PPO}$ in a hot environment $\left(30^{\circ} \mathrm{C}, 50 \% \mathrm{rh}\right)$ whilst consuming $1.25 \mathrm{~g} . \mathrm{kg}^{-1}$ body mass of the beverage every 10 minutes, before undertaking a $10 \mathrm{~km}$ time-trial (TT). Effects of the drink condition on dependent variables were assessed by repeated measures ANOVA with post-hoc $t$-tests and significance set at $\mathrm{P}<0.05$.

\section{Results}

TTs were faster in LIC (18.74(1.24) min) and ISC (18.64 (1.08) min) than IS (19.47(1.49) min), with a trend for LIC and ISC to be faster than LI $(19.78(2.18) \mathrm{min})$. Upon commencing fixed intensity exercise rectal temperature $\left(\mathrm{T}_{\mathrm{re}}\right)$ was lower with IS drinks $\left(\sim 0.3{ }^{\circ} \mathrm{C}\right)$, but this difference was largely abolished before the TT; skin temperature was unaffected by beverage. Fat oxidation tended to be lower with LIC and ISC $(P=0.06)$ relative to IS at the end of the fixed intensity exercise and thermal comfort and sensation were improved with IS beverages, although RPE was unaffected.

\section{Discussion}

Carbohydrate beverages were ergogenic following prolonged exercise in the heat and this effect was apparent with cold liquid and IS beverages, indicating that the IS did not meaningfully impair the benefits of exogenous carbohydrate supplementation. IS beverages reduced resting $\mathrm{T}_{\mathrm{re}}$ in the heat, but this effect did not persist following prolonged exercise, even with continued consumption. However IS drinks did provide some favourable perceptual benefits in terms of improved thermal comfort and sensation, although these did not influence performance.

\section{Conclusion}

An IS beverage containing carbohydrate is an appropriate choice for individuals engaging in prolonged exercise in the heat, in terms of combining perceptual and performance benefits.

\footnotetext{
* Correspondence: jo.corbett@port.ac.uk

Extreme Environments Laboratory, Department of Sport and Exercise

Science, University of Portsmouth, Portsmouth, UK
} 
Published: 14 September 2015

\section{References}

1. Siegel R, Laursen PB: Keeping Your Cool. Sports Med 2012, 42:89-98.

2. Siegel $R$, Maté J, Brearley MB, et al: Ice slurry ingestion increases core temperature capacity and running time in the heat. Med Science Sports Exerc 2010, 42:17-725.

3. Davis JM, Lamb DR, Pate RR, et al: Carbohydrate-electrolyte drinks: effects on endurance cycling in the heat. Am J Clin Nutr 1988, 48:1023-1030.

4. Jentjens RL, Wagenmakers AJ, Jeukendrup AE: Heat stress increases muscle glycogen use but reduces the oxidation of ingested carbohydrates during exercise. J Appl Physiol 2002, 92:1562-1572.

doi:10.1186/2046-7648-4-S1-A123

Cite this article as: Corbett et al:: Effects of ice-slurry and carbohydrate on exercise in the heat. Extreme Physiology \& Medicine 2015 4(Suppl 1): A123.

\section{Submit your next manuscript to BioMed Central} and take full advantage of:

- Convenient online submission

- Thorough peer review

- No space constraints or color figure charges

- Immediate publication on acceptance

- Inclusion in PubMed, CAS, Scopus and Google Scholar

- Research which is freely available for redistribution

Submit your manuscript at www.biomedcentral.com/submit 